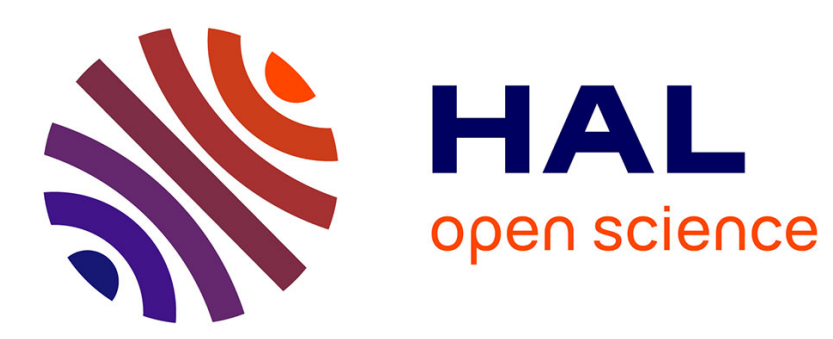

\title{
Socioeconomic position and hypertension: a study of urban civil servants in Ghana
}

Juliet Addo, Liam Smeeth, David A Leon

\section{To cite this version:}

Juliet Addo, Liam Smeeth, David A Leon. Socioeconomic position and hypertension: a study of urban civil servants in Ghana. Journal of Epidemiology and Community Health, 2009, 63 (8), pp.646-n/a. 10.1136/jech.2008.081828 . hal-00477882

\section{HAL Id: hal-00477882 \\ https://hal.science/hal-00477882}

Submitted on 30 Apr 2010

HAL is a multi-disciplinary open access archive for the deposit and dissemination of scientific research documents, whether they are published or not. The documents may come from teaching and research institutions in France or abroad, or from public or private research centers.
L'archive ouverte pluridisciplinaire HAL, est destinée au dépôt et à la diffusion de documents scientifiques de niveau recherche, publiés ou non, émanant des établissements d'enseignement et de recherche français ou étrangers, des laboratoires publics ou privés. 


\section{Socioeconomic position and hypertension: a study of urban civil servants in Ghana}

JULIET ADDO, LIAM SMEETH, DAVID A LEON

Department of Epidemiology and Population Health, London School of Hygiene and Tropical Medicine, Keppel Street, London WC1E 7HT, UK

Address for Correspondence:

Dr. JULIET ADDO

Postal address: London School of Hygiene and Tropical Medicine,

Department of Epidemiology and Population Health, Keppel Street, London WC 1E 7HT, UK

Email: Juliet.addo@1shtm.ac.uk

Telephone: 44(0)20 79272296

Fax: 44(0)20 75806897 


\section{Abstract}

Background: The association of socioeconomic position and cardiovascular disease risk factors in low and middle income countries has not been as consistent as that reported from the high income countries.

Methods: A cross sectional study of 1015 participants from 7 civil service departments in Accra, Ghana was conducted in 2006. Hypertension was diagnosed when the mean of a second and third blood pressure reading on each of two visits three weeks apart was $\geq 140 / 90 \mathrm{mmHg}$ or where participants were already diagnosed and on antihypertensive drugs. Socioeconomic measures considered were education, early life and adult wealth and civil service employment grade.

Results: The age-adjusted prevalence of hypertension was lowest in participants of lower socioeconomic position (21.9\% ; CI 16.3-27.5) and highest in those of highest socioeconomic position (31.8\%; CI 23.4-40.2) with inconsistent patterns among participants in the intermediate socioeconomic groups. Participants in the highest employment grade category were more likely to have hypertension than those in the lowest category (OR 1.91; CI 1.14-3.20). There was a positive graded association between adult wealth and hypertension with more assets associated with a greater risk (p-trend 0.008 ). This trend was partly explained by body mass index differences. Blood pressure control among those with diagnosed hypertension was generally poor across the socioeconomic strata.

Conclusions: In low income countries such as Ghana, there is a need to promote primary prevention of hypertension across the socioeconomic strata with focus on weight control among civil servants of higher socioeconomic position, and better hypertension control in those with hypertension. 


\section{Introduction}

There is good evidence that in developed, high income countries socioeconomic position (SEP) is inversely associated with cardiovascular disease morbidity, mortality and levels of cardiovascular disease (CVD) risk factors including hypertension.[1,2,3,4,5,6,7] However, in low and middle-income countries, sections of the population that undergo more rapid social development may also increase their risk factors for CVD and thus be at a greater risk of disease compared to people who are less well-off.[8] As the epidemic of cardiovascular disease advances however, the social gradient may reverse with the poor becoming the most vulnerable, a phenomena already evident in India.[9] Findings from sub-Saharan Africa (SSA) have been inconsistent with some studies reporting an inverse association between SEP and risk factors of CVD such as hypertension,[10,11,12,13] and a positive association reported in others.[14,15,16,17] A higher prevalence of hypertension has however been reported more consistently in urban populations in SSA compared to rural populations in studies that have compared this.[18,19] Various indicators of SEP have been used in health research. These include education, employment status, employment grade, housing tenure, housing conditions and amenities, income, occupation, wealth and area level measures.[1,4,20,21] It has been suggested that to show the full extent of socioeconomic differentiation in disease risk, there is a need for studies to collect measures of SEP across the life course and to use combined indicators of SEP.[22]

The purpose of our study was to examine the association between some indicators of SEP (adulthood and pre-adulthood) and the prevalence and control of hypertension in a wellcharacterised representative sample of urban civil servants in Ghana. 


\section{Methods}

A cross-sectional study of hypertension was conducted among civil servants in Accra between January and September 2006. The Republic of Ghana is centrally located in West Africa with a population of 22 million and a Gross National Income (GNI) per capita of $\$ 590$ a year. The capital city of Ghana is Accra in the Greater Accra Region which has a population of 3 million. It is predominantly urban (87.7\%) and is the most densely populated city in Ghana with 895.5 persons per square km. The Civil service forms part of the Public Service of Ghana and is an organised body of men and women employed by the government to assist it in the governance of Ghana. There are currently 26 ministries within the Ghanaian civil service. The Central Administration in Accra has a workforce of $8317(65.8 \%$ men, 34.2\% women).

The study involved seven central government ministries selected randomly from a list of all 26 civil service ministries in Accra, Ghana. All workers in the central administration offices of these seven ministries aged 25 years and above were invited to participate. The civil service ministries sampled for the study were Education, Foreign Affairs, Information, Agriculture, Local Government and Rural Development, Environment and Science and the Office of the Head of Civil Service. Pregnant women were excluded from the study. The protocol was approved by the ethics committees of the University of Ghana Medical School and the London School of Hygiene and Tropical Medicine and written informed consent was obtained from each participant before inclusion into the study.

A team of 10 pre-university students, a nutritionist and a medical doctor was trained to administer questionnaires and perform anthropometric and blood pressure measurements on the participants. The questionnaire explored socio-demographic and health-related variables. Blood 
pressure (BP) was measured after participants had been sitting quietly for at least ten minutes in a quiet environment using an electronic device (Omron M5I). Three measurements were taken at one minute interval on the right arm in a seated position, with arm supported at heart level and feet flat on the floor using an appropriate sized cuff. Blood pressure measurements were repeated three weeks after the first when systolic BP (SBP) was $\geq 140 \mathrm{mmHg}$ and/or diastolic BP (DBP) $\geq$ $90 \mathrm{mmHg}$ in participants not on antihypertensive treatment. Hypertension was diagnosed when the mean of the second and third BP measurements at both visits was $\geq 140 / 90 \mathrm{mmHg}$ or when participants reported the use of antihypertensive medication.[23,24] Treatment of hypertension was defined as self-reported current use of recognised antihypertensive medication among those defined as having hypertension whilst control of hypertension was defined as pharmacological treatment of hypertension associated with blood pressure of $<140 / 90 \mathrm{mmHg}$.

The socioeconomic factors considered were civil service employment grade, educational level attained and wealth based on household ownership of amenities such as a flush toilet, electricity, a refrigerator, a family car and a television. These household assets are indicators that reliably reflect income and economic resources in Ghana and have been used in assessing wealth in studies from other parts of Africa.[12] A typical middle class household in Ghana generally has all of these assets while those of lower socioeconomic position usually have few or none of these assets in their households and are inclined to use public and communal facilities available to them. Pre-adult wealth was assessed by the availability of these assets to the family or household during childhood and the current wealth by their availability currently. The participants were categorised into 4 groups ranging from those who had none to those with all five assets of interest. Participants were also classified according to which of the four civil service employment 
grade categories they were in : Directors (the highest grade made up of senior administrators and managers); Professional (professional staff not in managerial positions); Clerical (secretarial and records staff); Unskilled (the lowest grade made up of labourers, cleaners, drivers, catering and security staff). In terms of education, participants were classified as "Primary" where they had completed 9 years of education or less, "Secondary" where they had completed Senior Secondary School comprising 10 to 12 years of education; and "Tertiary" where participants had completed university education or higher (13 years or more).

All data forms were entered in Excel and were checked for range and internal consistency. Analysis was conducted using STATA 10.0 for windows (Stata Corporation, College Station, Texas, USA). Multivariate logistic regression models were performed to examine the associations between hypertension as well as control of hypertension and the socioeconomic variables of interest, adjusting for sex and age (treating age as a continuous variable). Multivariate censored regression models were additionally used as a sensitivity analysis to examine the associations between systolic and diastolic blood pressure and the socioeconomic variables of interest, adjusting for potentially confounding variables. Tests for trend were determined for each model based on regression analysis with the relevant factor entered as a continuous variable. We considered the possibility of interaction between sex and age and the socioeconomic indicators and introduced interaction parameters into the regression models to test for interaction formally using the likelihood ratio test. Analyses of the relationship between hypertension and the socioeconomic indicators were performed on participants with no missing data in any of the variables included in the models $(n=1007)$. Prevalence of hypertension was directly age-standardised to the WHO world standard population.[25] 


\section{Results}

A total of 1015 out of 1227 eligible civil servants participated in the study, a response rate of $82.7 \%$. Of the 1015 participants, $615(60.6 \%)$ were men. The mean age ( \pm standard deviation) in the study population was $44.0( \pm 10.2)$ years.

The majority of participants $(41 \%)$ had been educated to tertiary level or higher while $28 \%$ were either uneducated or had education only up to primary school. The pre-adult and adult levels of wealth of participants were determined from the availability of five specified amenities to the household. A small proportion of the study group (3\%) currently had none of these whilst $31 \%$ had all five assets compared to the pre-adult period when $29 \%$ of the participants had none of these assets and only $16 \%$ had all five amenities. As expected, directors had more assets currently compared to the unskilled workers, with $67 \%$ of directors having all five assets compared to $5 \%$ of the unskilled workers. The distribution of the age, body mass index and socioeconomic variables is presented by gender and employment grade in Table 1. 
Table 1 Characteristics of study population by employment grade and sex

\begin{tabular}{|c|c|c|c|c|c|c|c|c|c|}
\hline & \multicolumn{5}{|c|}{ Men } & \multicolumn{4}{|c|}{ Women } \\
\hline & $\begin{array}{l}\text { Unskilled } \\
\text { (n) } \\
\mathbf{1 6 4}\end{array}$ & $\%$ & $\begin{array}{l}\text { Clerical \% (n) } \\
105\end{array}$ & $\begin{array}{l}\text { Professional \% (n) } \\
253\end{array}$ & $\begin{array}{l}\text { Director \% (n) } \\
93\end{array}$ & $\begin{array}{l}\text { Unskilled \% (n) } \\
47\end{array}$ & $\begin{array}{l}\text { Clerical \% (n) } \\
200\end{array}$ & $\begin{array}{l}\text { Professional \% (n) } \\
127\end{array}$ & $\begin{array}{l}\text { Director \% (n) } \\
26\end{array}$ \\
\hline \multicolumn{10}{|l|}{ Age groups (years) } \\
\hline$<35$ & $16.5(27)$ & & $23.8(25)$ & $23.3(59)$ & $15.1(14)$ & $10.6(5)$ & $35.5(71)$ & $22.8(29)$ & $7.7(2)$ \\
\hline $35-44$ & $28.1(46)$ & & $16.2(17)$ & $27.3(69)$ & $25.8(24)$ & $19.2(9)$ & $18.0(36)$ & $28.4(36)$ & $46.2(12)$ \\
\hline $45-54$ & $32.9(54)$ & & $38.1(40)$ & $34.8(88)$ & $38.7(36)$ & $34.0(16)$ & $34.5(69)$ & $35.4(45)$ & $38.5(10)$ \\
\hline$>=55$ & $22.6(37)$ & & $21.9(23)$ & $14.6(37)$ & $20.4(19)$ & $36.2(17)$ & $12.0(24)$ & $13.4(17)$ & $7.7(2)$ \\
\hline \multicolumn{10}{|l|}{$\begin{array}{l}\text { Body Mass index } \\
\left(\mathrm{kg} / \mathbf{m}^{2}\right)\end{array}$} \\
\hline Underweight $(<18.5)$ & $6.1(10)$ & & $5.7(6)$ & $2.4(6)$ & $3.2(3)$ & $6.4(3)$ & $4.5(9)$ & $1.6(2)$ & 0 \\
\hline Normal (18.5-24.9) & $62.8(103)$ & & $56.2(59)$ & $49.0(124)$ & $36.6(34)$ & $29.8(14)$ & $27.5(55)$ & $27.6(35)$ & $15.4(4)$ \\
\hline Overweight (25.0-29.9) & $23.8(39)$ & & $32.4(34)$ & $36.8(93)$ & $46.2(43)$ & $27.7(13)$ & $32.0(64)$ & $40.2(51)$ & $30.8(8)$ \\
\hline Obese $(>=30.0)$ & $7.3(12)$ & & $5.7(6)$ & $11.9(30)$ & $14.0(13)$ & $36.2(17)$ & $36.0(72)$ & $30.7(30)$ & $53.9(14)$ \\
\hline \multicolumn{10}{|l|}{ Level of education } \\
\hline Primary ( $\leq 9$ years) & $79.9(131)$ & & $27.6(29)$ & $11.5(29)$ & 0 & $80.9(38)$ & $18.0(36)$ & $11.0(14)$ & 0 \\
\hline Secondary (10-12 years) & $17.7(29)$ & & $52.4(55)$ & $23.7(60)$ & $9.7(9)$ & 14.9 (7) & $56.0(112)$ & $56.0(112)$ & $15.4(4)$ \\
\hline Tertiary $(\geq 13$ years $)$ & $1.8(3)$ & & $18.1(19)$ & $64.8(164)$ & $89.2(83)$ & $2.1(1)$ & $25.5(51)$ & $25.5(51)$ & $80.8(21)$ \\
\hline Missing data & $0.6(1)$ & & $1.9(2)$ & 0 & $1.1(1)$ & $2.1(1)$ & $0.5(1)$ & $0.5(1)$ & $3.8(25)$ \\
\hline \multicolumn{10}{|l|}{ Current wealth } \\
\hline 2 or less assets & $32.9(54)$ & & $14.3(15)$ & $6.7(17)$ & $2.2(2)$ & $23.4(11)$ & $7.0(14)$ & $2.4(3)$ & 0 \\
\hline 3 assets & $39.0(64)$ & & $32.4(34)$ & $19.8(50)$ & $9.7(9)$ & $44.7(21)$ & $22.5(45)$ & $20.5(26)$ & $3.9(1)$ \\
\hline 4 assets & $24.4(40)$ & & $30.5(32)$ & $38.3(97)$ & $23.7(22)$ & $21.3(10)$ & $38.0(76)$ & $38.6(49)$ & $19.2(5)$ \\
\hline 5 assets & $3.7(6)$ & & $22.9(24)$ & $35.2(89)$ & $64.5(60)$ & $10.6(5)$ & $32.5(65)$ & $38.6(49)$ & $76.9(20)$ \\
\hline \multicolumn{10}{|l|}{ Pre-adult wealth } \\
\hline 1 or 2 assets & $20.1(33)$ & & $18.1(19)$ & $15.4(39)$ & $16.1(15)$ & $31.9(15)$ & $16.5(33)$ & $12.6(16)$ & $11.5(3)$ \\
\hline 3 or 4 assets & $26.2(43)$ & & $39.1(41)$ & $39.9(101)$ & $26.9(25)$ & 27.7913) & $52.5(105)$ & $40.2(51)$ & $26.9(7)$ \\
\hline 5 assets & $3.1(5)$ & & $13.3(14)$ & $16.2(41)$ & $20.4(19)$ & $12.8(6)$ & $15.5(31)$ & $27.6(35)$ & $57.7(15)$ \\
\hline
\end{tabular}


Table 2 shows the age-standardised prevalence of hypertension in participants of different socioeconomic position and the results of multivariate logistic regression analyses modelling the associations between hypertension and socioeconomic variables adjusted for age and sex. Results of multivariate censored regression analysis using systolic and diastolic blood pressure as outcomes were broadly similar to the results with hypertension as the outcome variable. The prevalence of hypertension was lowest among participants in the lowest grade of employment and with the fewest assets currently and highest among those in the highest grade of employment and those with the most assets both currently and in the pre-adult period. Participants in the highest employment grade category were more likely to have hypertension than those in the lowest category (OR 1.91; CI 1.14-3.20), and the trend higher employment grade - increased risk of hypertension, was weakly significant $(\mathrm{p}=0.05)$. There was a suggestion of an inverse association between the level of education and the risk of hypertension (higher education-lower risk) after adjusting for other indicators of socioeconomic position but this was not statistically significant. There was a positive graded association between adult wealth and hypertension with more assets associated with greater risk (p-trend 0.008) but no significant association between pre-adult wealth and hypertension. The association between adult wealth and hypertension was weakened when BMI was included in the model and the trend ceased to be statistically significant. 
Table 2 Prevalence and odds ratio (OR) of hypertension in the study population by categories of socioeconomic position

\begin{tabular}{|c|c|c|c|c|c|}
\hline $\begin{array}{l}\text { Socioeconomic } \\
\text { variables }\end{array}$ & $\begin{array}{l}\text { Number with } \\
\text { hypertension/ Total } \\
\text { number }\end{array}$ & $\begin{array}{l}\text { Age-standardised }^{\text {a }} \\
\text { prevalence of hypertension } \\
\%(95 \% \text { CI })\end{array}$ & $\begin{array}{l}\text { Model 1 } \\
\text { OR (95\% CI) }\end{array}$ & $\begin{array}{l}\text { Model } 2 \\
\text { OR }(95 \% \text { CI })\end{array}$ & $\begin{array}{l}\text { Model 3 } \\
\text { OR (95\% CI) }\end{array}$ \\
\hline \multicolumn{6}{|l|}{ Employment grade } \\
\hline Unskilled & $56 / 209$ & $21.9(16.3-27.5)$ & 1.00 & 1.00 & 1.00 \\
\hline Clerical & $94 / 302$ & $30.6(25.4-35.8)$ & $1.79(1.15-2.79)$ & $1.75(1.05-2.92)$ & $1.71(1.02-2.86)$ \\
\hline Professional & $109 / 379$ & $26.6(22.2-31.0)$ & $1.41(0.94-2.12)$ & $1.52(0.89-2.58)$ & $1.44(0.85-2.46)$ \\
\hline \multirow[t]{2}{*}{ Director } & $45 / 117$ & $31.8(23.4-40.2)$ & $1.91(1.14-3.20)$ & $2.17(1.09-4.34)$ & $1.98(0.99-3.98)$ \\
\hline & & & p-trend 0.05 & p-trend 0.09 & p-trend 0.15 \\
\hline \multicolumn{6}{|l|}{ Level of education } \\
\hline Primary ( $\leq 9$ years) & $93 / 277$ & $28.5(23.2-33.8)$ & 1.00 & 1.00 & 1.00 \\
\hline Secondary (10-12 years ) & $101 / 314$ & $29.9(24.8-35.0)$ & $1.32(0.91-1.92)$ & $0.94(0.60-1.47)$ & $0.94(0.60-1.48)$ \\
\hline \multirow[t]{2}{*}{ Tertiary ( $\geq 13$ years) } & $110 / 416$ & $27.0(22.7-31.30$ & $1.09(0.76-1.56)$ & $0.64(0.38-1.06)$ & $0.67(0.40-1.12)$ \\
\hline & & & p-trend 0.70 & p-trend 0.07 & p-trend 0.10 \\
\hline \multicolumn{6}{|l|}{ Current wealth } \\
\hline 2 or less assets & $27 / 116$ & $18.5(11.4-25.6)$ & 1.00 & 1.00 & 1.00 \\
\hline 3 assets & $75 / 247$ & $27.6(22.0-33.2)$ & $1.72(1.00-2.96)$ & $1.71(0.97-3.01)$ & $1.60(0.91-2.84)$ \\
\hline 4 assets & $99 / 327$ & $26.9(22.1-31.7)$ & $1.85(1.09-3.14)$ & $1.81(1.02-3.21)$ & $1.61(0.90-2.88)$ \\
\hline \multirow[t]{2}{*}{5 assets } & $103 / 317$ & $28.7(23.7-33.7)$ & $2.18(1.28-3.70)$ & $2.04(1.10-3.77)$ & $1.67(0.90-3.12)$ \\
\hline & & & p-trend 0.008 & p-trend 0.05 & p-trend 0.23 \\
\hline \multicolumn{6}{|l|}{ Pre-adult wealth } \\
\hline 1 or 2 assets & $52 / 172$ & $26.0(19.4-32.6)$ & $0.90(0.58-1.38)$ & $0.83(0.53-1.29)$ & $0.83(0.53-1.30)$ \\
\hline 3 or 4 assets & $101 / 381$ & $26.4(22.0-30.8)$ & $1.00(0.70-1.44)$ & $0.86(0.59-1.25)$ & $0.79(0.54-1.16)$ \\
\hline \multirow[t]{2}{*}{5 assets } & $44 / 165$ & $31.0(23.9-38.1)$ & $1.38(0.85-2.23)$ & $1.20(0.73-2.00)$ & $1.18(0.71-1.98)$ \\
\hline & & & p-trend 0.33 & p-trend 0.91 & p-trend 0.87 \\
\hline
\end{tabular}

a standardised to the World Health Organization Standard Population

Model 1 adjusted for age and sex

Model 2 adjusted for age, sex and pre-adult and current wealth, employment grade and level of education

Model 3 adjusted for age, sex, pre-adult and current wealth, employment grade, level of education and BMI 
Table 3 shows the results of multivariate logistic regression analyses modelling the associations between control of hypertension among those with hypertension and socioeconomic variables adjusted for age, sex and treatment of hypertension. There were suggestions of a positive gradient between employment grade and the control of hypertension (higher employment gradehigher control rate). The trend was weakly significant $(\mathrm{p}=0.06)$ and was partly explained by employment grade differences in hypertension treatment. Hypertensive participants who had completed secondary education were more likely to be controlled than those with only primary education but the trend higher level of education- better control was not statistically significant. There was no statistically significant association between assets owned both currently and in the pre-adult period and hypertension control. 
Table 3 Odds ratio of hypertension control among participants with hypertension and categories of socioeconomic position

\begin{tabular}{|c|c|c|c|}
\hline $\begin{array}{l}\text { Socioeconomic } \\
\text { variables }\end{array}$ & $\begin{array}{l}\text { Control of } \\
\text { hypertension \% (n/N) }\end{array}$ & $\begin{array}{l}\text { Model } 1 \\
\text { OR }(95 \% \text { CI })\end{array}$ & $\begin{array}{l}\text { Model } 2 \\
\text { OR }(95 \% \text { CI })\end{array}$ \\
\hline $\begin{array}{l}\text { Employment grade } \\
\text { Unskilled } \\
\text { Clerical } \\
\text { Professional } \\
\text { Director } \\
\text { p-trend }\end{array}$ & $\begin{array}{l}3.5(2 / 57) \\
17.0(16 / 94) \\
13.8(15 / 109) \\
12.8(6 / 47)\end{array}$ & $\begin{array}{l}1.00 \\
2.79(0.58-13.43) \\
3.46(0.72-16.65) \\
5.23(0.91-30.07) \\
0.06\end{array}$ & $\begin{array}{l}1.00 \\
2.09(0.37-11.86) \\
3.11(0.54-18.07) \\
4.30(0.60-31.03) \\
0.11\end{array}$ \\
\hline $\begin{array}{l}\text { Level of education } \\
\text { Primary ( } \leq 9 \text { years) } \\
\text { Secondary (10-12 years) } \\
\text { Tertiary ( } \geq 13 \text { years) } \\
\text { p-trend }\end{array}$ & $\begin{array}{l}6.5(6 / 93) \\
21.8(22 / 101) \\
9.1(10 / 110)\end{array}$ & $\begin{array}{l}1.00 \\
2.95(1.08-8.08) \\
1.55(0.51-4.71) \\
0.57\end{array}$ & $\begin{array}{l}1.00 \\
3.22(1.03-10.08) \\
1.53(0.43-5.42) \\
0.67\end{array}$ \\
\hline $\begin{array}{l}\text { Current wealth } \\
2 \text { or less assets } \\
3 \text { assets } \\
4 \text { assets } \\
5 \text { assets } \\
\text { p-trend }\end{array}$ & $\begin{array}{l}14.8(4 / 27) \\
7.9(6 / 76) \\
12.0(12 / 100) \\
16.4(17 / 104)\end{array}$ & $\begin{array}{l}1.00 \\
0.33(0.08-1.45) \\
0.44(0.11-1.72) \\
0.60(0.16-2.28) \\
0.81\end{array}$ & $\begin{array}{l}1.00 \\
0.22(0.36-1.3) \\
0.25(0.05-1.34) \\
0.35(0.07-1.81) \\
0.83\end{array}$ \\
\hline $\begin{array}{l}\text { Pre-adult wealth } \\
\text { none } \\
1 \text { or } 2 \text { assets } \\
3 \text { or } 4 \text { assets } \\
5 \text { assets } \\
\text { p-trend }\end{array}$ & $\begin{array}{l}6.5(7 / 108) \\
7.7(4 / 52) \\
19.6(20 / 102) \\
17.8(8 / 45)\end{array}$ & $\begin{array}{l}1.00 \\
1.00(0.26-3.77) \\
2.23(0.85-5.83) \\
1.80(0.55-5.89) \\
0.14\end{array}$ & $\begin{array}{l}1.00 \\
0.73(0.17-3.17) \\
1.81(0.62-5.3) \\
1.22(0.31-4.72) \\
0.41\end{array}$ \\
\hline
\end{tabular}

$\mathrm{n}=$ number of hypertensive participants with controlled hypertension

$\mathrm{N}=$ number of participants with diagnosed hypertension

Model 1 adjusted for age and sex

Model 2 adjusted for age, sex and treatment of hypertension 


\section{Discussion}

This study of hypertension in an urban working population showed a lower prevalence of hypertension in participants of lower SEP and highest prevalence in those of the highest SEP with an inconsistent pattern among participants in the intermediate socioeconomic groups. There was a significant positive graded association between current level of wealth and hypertension which was partly explained by BMI. There was a suggested negative association between the level of education and hypertension after controlling for the other measures of SEP. There were suggestions of a positive gradient between employment grade and the control of hypertension (higher employment grade- higher control rate) with a weakly significant trend. Hypertensive participants who had completed secondary education were more likely to be controlled than those with only primary education.

In a review of published literature to assess the association between socio-economic position (SEP) and blood pressure, high mean blood pressure or prevalence of hypertension was associated with low SEP in almost all studies from North America and most from Europe, regardless of the measure of SEP used. A positive association was reported in many of the studies from low and middle income countries.[6] In the Whitehall study of London based civil servants, mean blood pressure and prevalence of hypertension were higher among men in the lower grades of employment, contrary to the finding of a lower prevalence of hypertension in the unskilled workers in our study.[26] Interestingly, the current inverse trend observed in developed countries (lower socioeconomic position-higher cardiovascular disease), has not always been so. Analysis of mortality trends for England and Wales showed that whereas in 1931 and 1951 heart disease was more common in men of social classes I and II, by 1961 it was more common in 
men of classes IV and V.[27] A systematic review of the relationship between socioeconomic position and ischaemic heart disease reported a lower risk among manual versus non-manual workers until approximately 1970 with the relationship becoming inverted thereafter. [28] Possible explanations given for the change in social class distribution were the differences in diet and smoking habits between the social classes, and the changes in diagnostic methods over the period. The studies included in the review had mainly included males in high income countries and limits the ability to extrapolate to other groups. In low income countries however, sections of the population that undergo more rapid social development may also increase their risk factors for CVD and thus be at a greater risk of disease compared to people who are less well-off.[8] Civil servants of higher SEP in Ghana are more likely to be engaged in jobs that are sedentary, have the availability of automated transport and afford more processed foods which are currently more expensive than the indigenous diets. An increase in the consumption of processed foods high in fats and salts, and a decrease in the level of physical activity both at work and leisure, possibly contributes to higher levels of obesity and ultimately to the development of hypertension.

Interestingly, there were suggestions of an inverse association between the risk of hypertension and the level of education contrary to the positive association observed with employment grade and current assets in this population. A study of low income rural women in Mexico had similarly observed an inverse association between educational attainment and systolic blood pressure and a positive association with income, housing and asset index and suggested that different aspects of socioeconomic status provided different aspects of protection as well as risk.[29] 
An adverse environment during critical periods of development in foetal life and infancy have been suggested to predispose individuals to unfavourable profile of cardiovascular disease risk factors and mortality in later life.[30,31] Blood pressure, whether studied in children or adults, has been reported to be inversely related to birth weight.[32,33,34] However, in our study early life factors, as measured by pre-adult wealth was not associated with hypertension.

There was a weakly significant positive gradient between the control of hypertension and employment grade which was partly explained by the differences in hypertension treatment. Hypertensive participants who had completed secondary education were more likely to be controlled than those with only primary education. The associations between the other indicators of SEP and the control of hypertension were however not statistically significant. These findings possibly reflect an inadequate understanding of hypertension and the need to be treated continuously for it even in the absence of symptoms among unskilled workers and participants educated only to primary level. It is also possible that those in the lower employment grades are unable to afford the high costs of medication for hypertension and are non-compliant with their antihypertensive treatment even when prescribed, resulting in the lower control rates.

Our study of civil servants had some limitations. The sample was deliberately not representative of the entire Ghanaian population, but was selected as a sentinel group, many of whom have taken on a more developed country lifestyle at an early stage. In addition, the role of other possible explanatory factors for hypertension such as stress, type of personality and salt intake were not investigated. Despite these limitations, the findings from our study indicate a need to promote the adoption of healthy lifestyles by all civil servants regardless of SEP as a means of 
primary prevention of hypertension with emphasis on maintaining ideal body weight and to develop appropriate strategies for better control of hypertension. 


\section{References}

1. Kaplan, G.A. ;Keil, J.E.(1993) Socioeconomic factors and cardiovascular disease: a review of the literature. Circulation, 88, 1973-1998.

2. Kunst, A.E. ;del Rios, M. ;Groenhof, F. ;Mackenbach, J.P.(1998) Socioeconomic inequalities in stroke mortality among middle-aged men: an international overview. European Union Working Group on Socioeconomic Inequalities in Health. Stroke, 29, 2285-2291.

3. Kunst, A.E. ;Groenhof, F. ;Mackenbach, J.P. ;Health, E.W.(1998) Occupational class and cause specific mortality in middle aged men in 11 European countries: comparison of population based studies. EU Working Group on Socioeconomic Inequalities in Health. Bmj, 316, 1636-1642.

4. Marmot, M.G. ;Rose, G. ;Shipley, M. ;Hamilton, P.J.(1978) Employment grade and coronary heart disease in British civil servants. J Epidemiol Community Health, 32, 244-249.

5. Pocock, S.J. ;Shaper, A.G. ;Cook, D.G. ;Phillips, A.N. ;Walker, M.(1987) Social class differences in ischaemic heart disease in British men. Lancet, 2, 197-201.

6. Colhoun, H.M. ;Hemingway, H. ;Poulter, N.R.(1998) Socio-economic status and blood pressure: an overview analysis. J Hum Hypertens, 12, 91-110.

7. Seeman, T. ;Merkin, S.S. ;Crimmins, E. ;Koretz, B. ;Charette, S., et al.(2008) Education, income and ethnic differences in cumulative biological risk profiles in a national sample of US adults: NHANES III (1988-1994). Soc Sci Med, 66, 72-87.

8. Yusuf, S. ;Reddy, S. ;Ounpuu, S. ;Anand, S.(2001) Global burden of cardiovascular diseases: part I: general considerations, the epidemiologic transition, risk factors, and impact of urbanization. Circulation, 104, 2746-2753.

9. Reddy, K.S.(1993) Cardiovascular diseases in India. World Health Stat Q, 46, 101-107. 
10. Gupta, R. ;Gupta, V.P. ;Ahluwalia, N.S.(1994) Educational status, coronary heart disease, and coronary risk factor prevalence in a rural population of India. Bmj, 309, 1332-1336.

11. Rossouw, J.E. ;Jooste, P.L. ;Steenkamp, H.J. ;Thompson, M.L. ;Jordaan, P.C., et al.(1990) Socio-economic status, risk factors and coronary heart disease. The CORIS baseline study. S Afr Med J, 78, 82-85.

12. Bovet, P. ;Ross, A.G. ;Gervasoni, J.P. ;Mkamba, M. ;Mtasiwa, D.M., et al.(2002)

Distribution of blood pressure, body mass index and smoking habits in the urban population of Dar es Salaam, Tanzania, and associations with socioeconomic status. Int J Epidemiol, 31, 240-247.

13. Lang, T. ;Pariente, P. ;Salem, G. ;Tap, D.(1988) Social, professional conditions and arterial hypertension: an epidemiological study in Dakar, Senegal. J Hypertens, 6, 271-276.

14. Singh, R.B. ;Sharma, J.P. ;Rastogi, V. ;Niaz, M.A. ;Ghosh, S., et al.(1997) Social class and coronary disease in rural population of north India. The Indian Social Class and Heart Survey. Eur Heart J, 18, 588-595.

15. Pereira, M.A. ;Kriska, A.M. ;Collins, V.R. ;Dowse, G.K. ;Tuomilehto, J., et al.(1998) Occupational status and cardiovascular disease risk factors in the rapidly developing, high-risk population of Mauritius. Am J Epidemiol, 148, 148-159.

16. Bunker, C.H. ;Okoro, F.I. ;Markovic, N. ;Thai, N. ;Pippin, B., et al.(1996) Relationship of hypertension to socioeconomic status in a west African population. Ethn Health, 1, 33-45.

17. Bunker, C.H. ;Ukoli, F.A. ;Nwankwo, M.U. ;Omene, J.A. ;Currier, G.W., et al.(1992)

Factors associated with hypertension in Nigerian civil servants. Prev Med, 21, 710-722.

18. Mbanya, J.C. ;Minkoulou, E.M. ;Salah, J.N. ;Balkau, B.(1998) The prevalence of hypertension in rural and urban Cameroon. Int J Epidemiol, 27, 181-185. 
19. Sobngwi, E. ;Mbanya, J.C. ;Unwin, N.C. ;Porcher, R. ;Kengne, A.P., et al.(2004) Exposure over the life course to an urban environment and its relation with obesity, diabetes, and hypertension in rural and urban Cameroon. Int J Epidemiol, 33, 769-776.

20. Galobardes, B. ;Shaw, M. ;Lawlor, D.A. ;Lynch, J.W. ;Davey Smith, G.(2006) Indicators of socioeconomic position (part 2). J Epidemiol Community Health, 60, 95-101.

21. Galobardes, B. ;Shaw, M. ;Lawlor, D.A. ;Lynch, J.W. ;Davey Smith, G.(2006) Indicators of socioeconomic position (part 1). J Epidemiol Community Health, 60, 7-12.

22. Davey Smith, G. ;Hart, C. ;Hole, D. ;MacKinnon, P. ;Gillis, C., et al.(1998) Education and occupational social class: which is the more important indicator of mortality risk? J Epidemiol Community Health, 52, 153-160.

23. Chobanian, A.V. ;Bakris, G.L. ;Black, H.R. ;Cushman, W.C. ;Green, L.A., et al.(2003) The Seventh Report of the Joint National Committee on Prevention, Detection, Evaluation, and Treatment of High Blood Pressure: the JNC 7 report. Jama, 289, 2560-2572.

24. 1999) 1999 World Health Organization-International Society of Hypertension Guidelines for the Management of Hypertension. Guidelines Subcommittee. J Hypertens, 17, 151-183.

25. Ahmad OB ;Boschi-Pinto C ;Lopez AD ;Murray CJL ;Lozano R, et al.(Age standardization of rates: a new WHO standard. Global Programme on Evidence for Health Policy Discussion Paper Series: no.31. World Health Organization. Geneva, 2000.

26. Marmot MG.(Psychosocial factors and blood pressure. In Bulpitt CJ, ed. Handbook of Hypertension, Vol6: Epidemiology of hypertension. Amsterdam: Elsevier; 1985:89-101. 27. Marmot, M.G. ;Adelstein, A.M. ;Robinson, N. ;Rose, G.A.(1978) Changing social-class distribution of heart disease. Br Med J, 2, 1109-1112. 
28. Gonzalez, M.A. ;Rodriguez Artalejo, F. ;Calero, J.R.(1998) Relationship between socioeconomic status and ischaemic heart disease in cohort and case-control studies: 1960-1993. Int J Epidemiol, 27, 350-358.

29. Fernald, L.C. ;Adler, N.E.(2008) Blood pressure and socioeconomic status in low-income women in Mexico: a reverse gradient? J Epidemiol Community Health, 62, e8.

30. Barker, D.J. ;Martyn, C.N.(1992) The maternal and fetal origins of cardiovascular disease. J Epidemiol Community Health, 46, 8-11.

31. Smith GD (2004) Life course approaches to socioeconomic differentials in health. In: Kuh D, Ben Shlomo Y, editors. A life course approach to chronic disease epidemiology. 2nd ed: Oxford: OUP. pp. 77-115.

32. Barker, D.J. ;Osmond, C. ;Golding, J. ;Kuh, D. ;Wadsworth, M.E.(1989) Growth in utero, blood pressure in childhood and adult life, and mortality from cardiovascular disease. Bmj, 298, 564-567.

33. Gamborg, M. ;Byberg, L. ;Rasmussen, F. ;Andersen, P.K. ;Baker, J.L., et al.(2007) Birth Weight and Systolic Blood Pressure in Adolescence and Adulthood: Meta-Regression Analysis of Sex- and Age-specific Results from 20 Nordic Studies. Am J Epidemiol, 166, 634-645.

34. Law, C.M. ;Shiell, A.W.(1996) Is blood pressure inversely related to birth weight? The strength of evidence from a systematic review of the literature. J Hypertens, 14, 935-941. 


\section{What is known about this subject}

Lower socioeconomic position is reported to be associated with a higher prevalence of high blood pressure in most studies from high income countries with less clear patterns reported from low income countries including studies from sub Saharan Africa.

\section{What this study adds}

- Adds to the limited community-based data available on the association between socioeconomic position and hypertension in Africa.

- Provides evidence of a lower prevalence of hypertension among the lower socioeconomic group.

- Suggests a positive-graded association between hypertension and current wealth which is partly explained by the BMI. 


\section{Acknowledgements}

Sources of funding: Funding was from the Commonwealth Scholarship Commission and the Wingate Foundation, U.K. LS is supported by a Senior Research Fellowship in Clinical Science from the Wellcome Trust.

Conflict of interest declaration: There are no conflicts of interest.

Ethics approval : The protocol was approved by the ethics committees of the University of Ghana Medical School and the London School of Hygiene and Tropical Medicine and written informed consent was obtained from each participant before inclusion into the study.

Licence statement: The Corresponding Author has the right to grant on behalf of all authors and does grant on behalf of all authors, an exclusive licence (or non exclusive for government employees) on a worldwide basis to the BMJ Publishing Group Ltd and its Licensees to permit this article (if accepted) to be published in JECH editions and any other BMJPGL products to exploit all subsidiary rights, as set out in our licence (http://jech.bmj.com/ifora/licence.pdf) 